\title{
PENGARUH MODEL PEMBELAJARAN ARIAS (ASSURANCE, RELEVANCE, INTEREST, ASSESMENT, SATISFACTION) TERHADAP HASIL BELAJAR MATEMATIKA PESERTA DIDIK KELAS VII SMPN 1 SUNGGUMINASA KAB. GOWA
}

\author{
Anugrah Lestari ${ }^{1)}$, Nursalam ${ }^{2)}$, Mardhiah ${ }^{3)}$ \\ 1,2,3Fakultas Tarbiyah dan Keguruan UIN Alauddin Makassar \\ 1,2,3Kampus II: Jalan HM. Yasin Limpo Nomor 36 Samata-Gowa \\ E-mail: nursalam_ftk@uin-alauddin.ac.id²),
}

\begin{abstract}
Abstrak:
Penelitian ini bertujuan untuk mengetahui pengaruh model pembelajaran ARIAS terhadap hasil belajar matematika peserta didik kelas VII SMPN 1 Sungguminasa Kab. Gowa. Penelitian ini merupakan jenis penelitian experiment dengan desain penelitian posttest only control design. Teknik analisis data yang digunakan adalah analisis statistik deskriptif dan analisis statistik inferensial. Berdasarkan hasil analisis dengan menggunakan statistik deskriptif pada kelas eksperimen yakni nilai rata-rata posttest adalah 76,90 , sedangkan kelas kontrol nilai ratarata posttest adalah 65,32 kelompok. Hasil analisis inferensial diperolah $t$-hitung $>t$-tabel dimana, $t$-hitung $=3,492$ sedangkan $t$-tabel $=2,000$, maka berdasarkan kriteria pengujian dapat dikatakan bahwa terdapat perbedaan rata-rata hasil belajar matematika peserta didik yang diajar dengan model pembelajaran ARIAS dengaan model pembelajaran konvensional pada kelas VII SMP Negeri 1 Sungguminasa Kab. Gowa.
\end{abstract}

Kata Kunci: Model Pembelajaran ARIAS, Hasil Belajar

$\mathrm{P}$ endidikan adalah proses pengubahan sikap dan tata laku seseorang atau kelompok orang dalam usaha mendewasakan manusia melalui upaya pengajaran dan pelatihan. Pendidikan sangat berperan dalam membentuk baik atau buruknya pribadi manusia menurut ukuran normatif. Untuk menjadikan pribadi manusia yang baik maka diperlukan pendidikan yang berkualitas. Menurut Nursalam (2013:5) Peningkatan mutu atau kualitas pembelajaran merupakan inti dari reformasi pendidikan di Negara manapun. Peningkatan mutu pendidikan nasional, tergantung pada kualitas pembelajaran. Namun, peningkatan kualitas pembelajaran sangat bersifat kontekstual, sangat dipengaruhi oleh kondisi sosial dan kultural sekolah dan lingkungannya. Jadi pendidikan yang dikatakan berkualitas jika terus mengalami peningkatan dari segi kualitas pembelajaran yang dimana disesuaikan dengan kurikulum yang ditetapkan. 
Pendidikan mencakup luas berbagai bidang ilmu, salah satunya bidang ilmu matematika. Menurut Herumen (2007) Matematika merupakan salah satu bidang studi yang memiliki peranan penting dalam pendidikan. Penguasaan terhadap bidang studi matematika merupakan suatu keharusan, dengan belajar matematika orang dapat mengembangkan kemampuan berpikir secara sistematis, logis, kritis, dan kreatif yang sungguh dibutuhkan dalam kehidupan. Oleh sebab itu, matematika merupakan salah satu ilmu dasar yang perlu diajarkan di sekolah di setiap jenjang pendidikan karena penggunaannya yang luas pada aspek kehidupan dan memberikan peluang dimasa depan.

Menurut Hamalik (2001:29) Pembelajaran adalah suatu proses sosialisasi individu peserta didik dengan lingkungan, sekolah, guru, sumber atau fasilitas, dan semua peserta didik, dalam pembelajaran di sekolah bukan hanya bertujuan untuk mengumpulkan pengetahuan semata melainkan juga untuk membentuk sikap dan perbuatan serta menanamkan konsep dan kecekatan atau keterampilan. Seperti halnya dengan tujuan pencapain pembelajaran menurut taksonomi bloom yaitu harus mencangkup tiga domain yaitu: kognitif, afektif serta psikomotorik. Kawasan kognitif yang dimaksud dalam taksonomi bloom yaitu kawasan yang berkaitan dengan aspek-aspek intelektual atau berpikir seperti pengetahuan, pengertian, dan keterampilan berpikir. Kawasan afektif yaitu kawasan yang berkaitan aspekaspek emosional, seperti perasaan, minat, sikap, kepatuhan terhadap moral dan penilaian. Kawasan psikomotor yaitu kawasan yang berkaitan dengan aspek-aspek keterampilan yang melibatkan fungsi sistem syaraf dan otot serta fungsi psikis.

Menurut Badan Satndar Nasional Pendidikan (2006: 140) Pencapaian pembelajaran yang efektif dalam pembelajaran matematika juga harus mengetahui standar kompetensi mata pelajaran matematika dimana dalam peraturan Mendiknas RI No. 22 Tahun 2006, pemerintah merumuskan standar kompetensi mata pelajaran matematika, terdapat lima rumusan standar kompetensi yaitu memahami konsep matematika, menggunakan penalaran pada pola dan sifat, melakukan manipulasi matematika dalam membuat generalisasi, memecahkan masalah yang meliputi kemampuan memahami masalah, mengkomunikasikan gagasan dengan simbol, tabel, diagram, atau media lain untuk memperjelas keadaan atau masalah serta memiliki sikap menghargai kegunaan matematika dalam kehidupan. 
Menurut Damyati dan Madjimo (1999: 250) Hasil belajar merupakan salah satu acuan dalam keberhasilan sebuah proses pembelajaran oleh karena itu jika hasil belajar matematik peserta didik yang rendah akan menjadi ukuran dalam keberhasilan proses pembelajaran dan kualitasnya, daripemaparan di atas, maka diperlukan usaha dari guru untuk meningkatkan hasil belajar matematik peserta didik tersebut. Menurut Sudjana (1995:25) Usaha yang dapat dilakukan oleh guru antara lain adalah guru harus kreatif dan cerdas dalam memilih metode ajar kepada peserta didik misalnya menggunakan model motivasi yang bisa membuat peserta didik merasa nyaman dan termotivasi untuk belajar matematika sehingga dapat meningkatkan hasil belajar matematik peserta didik, salah satunya model pembelajaran ARIAS. Model pembelajaran ARIAS menjadi penawaran solusi untuk sekolah SMPN 1 Sungguminasa hal ini dikarenakan model ini menarik untuk membuat peserta didik berminat untuk belajar matematika yang nantinya akan berdampak bagus pada hasil belajar matematika peserta didik, karena dalam kegiatan model pembelajaran ARIAS terdapat lima komponen yang diterapkan yaitu Assurance, Relevance, Interst, Assesment, Satisfaction dimana lima komponen ini terdapat usaha untuk menanamkan rasa yakin/percaya diri, memberikan perhatian kepada peserta didik, merelevansikan pembelajaran dengan kehidupan sehari-hari, mengevaluasi pembelajaran dan memberikan penguatan pelajaran kepada peserta didik.

Pada model pembelajaran ARIAS, peserta didik dibawa untuk mengikuti proses belajar yang menyenangkan. Mula-mula pembelajaran ditekankan pada menumbuhkan kepercayaan diri peserta didik, misalnya dengan cara peserta didik mengemukakan pendapat kemudian materi pelajaran dikaitkan dengan lingkungan di sekitar peserta didik membuat ketertarikan peserta didik dengan pelajaran matematika. Langkah selanjutnya adalah mengevaluasi untuk menjadi alat untuk mengetahui apakah yang telah diajarkan sudah dipahami oleh peserta didik, dan langkah terakhir adalah memberikan pujian, memberikan hadiah dan memberikan nilai yang bagus sebagai upaya menimbulkan kepuasan pada diri peserta didik.

Berdasarkan hasil penelitian Penerapan model pembelajaran ARIAS dalam pembelajaran matematika yang diberikan pada peserta didik kelas IV SD Negeri Batur kecamatan kintamani peserta didik kelas IV yang erjumlah 56 peserta didik. Data hasil belajar dikumpulkan dengan menggunakan tes esai, yang dianalisis dengan menggunakan metode analisis statistik deskriptif dan statistik inferensial. Berdasarkan hasil penelitian tersebut dapat disimpulkan 
bahwa penggunaan model pembelajaran ARIAS dapat berpengaruh terhadap hasil belajar matematika pada peserta didik kelas IV di SD Negeri 5 Batur Kecamatan Kintamani. Selain itu, penelitian ini pertujuan pula untuk mengetahui pengaruh model pembelajaran ARIAS terhadap hasil belajar matematika peserta didik kelas VII SMPN 1 Sungguminasa Kab. Gowa.

\section{PEMBELAJARAN MATEMATIKA}

Pembelajaran dalam dunia pendidikan adalah suatu hal yang penting karena pembelajaran merupakan faktor yang membuat pendidikan menjadi lebih berkualitas. Menurut Yasin (2010:15) Pembelajaran merupakan proses dua arah, mengajar dilakukan oleh pihak guru sebagai pendidik, sedangkan belajar dilakukan peserta didik. Berarti dalam sebuah pembelajaran yang berperan penting adalah pendidik dan peserta didik. Oleh karena itu dapat disimpulkan bahwa pembelajaran matematika merupakan proses yang disengaja dirancang dengan tujuan untuk menciptakan suasana lingkungan yang memungkinkan peserta didik melaksanakan kegiatan belajar matematika. Dalam karakteristik proses pembelajaran matematika harus menekankan pemahaman konsep terhadap peserta didik karena konsep materi selalu saling berkaitan dengan konsep sebelumnya atau materi pembelajaran sebelumnya.

\section{MODEL PEMBELAJARAN ARIAS}

Model pembelajaran ARIAS merupakan modifikasi dari model ARCS. Model ARCS (Attention, Relevance, Confidence, Satisfaction), dikembangkan oleh Keller dan Kopp (1987) sebagai jawaban pertanyaan bagaimana merancang pembelajaran yang dapat mempengaruhi motivasi berprestasi dan hasil belajar. Menurut Endang (2014:105) Model pembelajaran ini dikembangkan berdasarkan teori nilai harapan (expectancy value theory) yang mengandung dua komponen yaitu nilai (value) dari tujuan yang akan dicapai dan harapan (expectancy) agar berhasil mencapai tujuan itu, dari dua komponen tersebut oleh Keller dikembangkan menjadi empat komponen.Menurut Slameto (2010:8) Keempat komponen model ARCS itu adalah attention, relevance, confidence dan satisfaction. Menurut Bohlin (1987: 11-14) Model pembelajaran ini menarik karena dikembangkan atas dasar teori-teori belajar dan pengalaman nyata para instruktur. Namun demikian, pada model pembelajaran ini tidak ada evaluasi (assessment), sedangkan model ARCS ini dikembangkan dari teori nilai dan harapan, padahal evaluasi merupakan 
komponen yang tidak dapat dipisahkan dalam kegiatan pembelajaran. Evaluasi yang dilaksanakan tidak hanya pada akhir kegiatan pembelajaran tetapi perlu dilaksanakan selama proses kegiatan berlangsung. Hal tersebut dilaksanakan untuk mengetahui sampai sejauh mana kemajuan yang dicapai atau hasil belajar yang diperoleh peserta didik. Evaluasi yang dilaksanakan selama proses pembelajaran menurut Saunders et. Al. (Rahman, 2014) dapat mempengaruhi hasil belajar peserta didik. Mengingat pentingnya evaluasi, maka model pembelajaran ARCS belum terdapat komopen evaluasi maka model ini dimodifikasi dengan menambahkan komponen evaluasi pada model pembelajaran tersebut. Penambahan komponen pada model ARCS berpengaruh pada akronimnya sehingga modifikasi juga dilakukan dengan penggantian nama dari akronim ARCS yaitu attention menjadi interest,karena pada kata interest (minat) sudah terkandung pengertian attention (perhatian),dengan kata interest tidak hanya sekedar menarik minat/perhatian peserta didik pada awal kegiatan melainkan tetap memelihara minat/perhatian tersebut selama kegiatanpembelajaran berlangsung. Confidence menjadi karena kata assurance sama dengan kata selfconfidence.Untuk memperoleh akronim yang lebih baik dan lebih bermaknamaka urutannya pun dimodifikasi menjadi assurance, relevance, interest, assessment dan satisfaction (ARIAS). Oleh karena itu, model pembelajaran yang sudah dimodifikasi ini disebut model pembelajaran ARIAS.

\section{PENERAPAN ARIAS DALAM PEMBELAJARAN MATEMATIKA}

Seperti yang telah dikemukakan model pembelajaran ARIAS terdiri dari lima komponen (Assurance, Relevance, Interest, Assessment, dan Satisfaction) yang sudah termodifikasi dan tersusun berdasarkan teori belajar. Kelima komponen tersebut merupakan satu kesatuan yang diperlukan dalam kegiatan pembelajaran berikut adalah langkah-langkah dalam model pembelajaran ARIAS yaitu:

\section{Assurance (Kepercayaan Diri)}

Menurut Rahman (2014:187) Assurance ataupun kepercayaan diri merupakan komponen model pembelajaran ARIAS yang pertama. Komponen ini memiliki hubungan dengan sikap percaya, yakin akan berhasil atau yang berhubungan dengan harapan untuk berhasil. Menurut Bandura seseorang yang memiliki sikap percaya diri tinggi cenderung akan berhasil 
bagaimanapun kemampuan yang ia miliki. Sikap di mana seseorang merasa yakin, percaya dapat berhasil mencapai sesuatu akan mempengaruhi mereka bertingkah laku untuk mencapai keberhasilan tersebut. Sikap ini mempengaruhi kinerja aktual seseorang, sehingga perbedaan dalam sikap ini menimbulkan perbedaan dalam kinerja.

Beberapa cara yang dapat digunakan untuk mempengaruhi sikap percaya diri adalah sebagai berikut:

a. Membantu peserta didik menyadari kekuatan dan kelemahan diri serta menanamkan pada peserta didik gambaran diri positif terhadap diri sendiri. Hal ini dapat dilakukan dengan menampilkan video ataupun gambar seseorang yang telah berhasil, dengan adanya ini, maka peserta didik akan bisa menanamkan gambaran positif terhadap diri sendiri.

b. Menggunakan suatu patokan atau standar yang memungkinkan peserta didik dapat mencapai keberhasilan (misalnya dengan mengatakan bahwa kamu tentu dapat menjawab pertanyaan di bawah ini tanpa melihat buku).

c. Memberi tugas yang sukar tetapi cukup realistis untuk diselesaikan atau sesuai dengan kemampuan peserta didik. Misalnya memberi tugas kepada peserta didik dimulai dari yang mudah berangsur sampai ke tugas yang sukar.

d. Memberi kesempatan kepada peserta didik secara mandiri dalam belajar dan melatih suatu keterampilan.

\section{Relevance (Relevansi)}

Menurut Rahman (2014: 188)Komponen kedua dari model pembelajaran ARIAS adalah relevance. Relevance berhubungan dengan kehidupan peserta didik baik berupa pengalaman sekarang atau yang berhubungan dengan kebutuhan karir sekarang atau yang akan dating Relevansi membuat peserta didik merasa kegiatan pembelajaran yang mereka ikuti memiliki nilai, bermanfaat dan berguna bagi kehidupan mereka. Peserta didik akan terdorong mempelajari sesuatu jika yang dipelajarinya terdapat relevansi dengan kehidupan mereka dan memiliki tujuan yang jelas. Sesuatu yang memiliki arah tujuan, sasaran yang jelas, manfaat dan relevan dengan kehidupan akan mendorong individu untuk mencapai tujuan tersebut dengan tujuan yang jelas. Mereka akan mengetahui kemampuan apa yang akan dimiliki dan pengalaman apa yang akan didapat. Mereka juga akan mengetahui kesenjangan antara kemampuan. Adapun cara-cara yang dapat 
dilakukan untuk mengembangkan komponen relevansi ini adalah sebagai berikut:

a. Mengemukakan tujuan sasaran yang akan dicapai. Tujuan yang jelas akan memberikan harapan yang jelas (kongkrit) pada peserta didik dan mendorong mereka untuk mencapai tujuan tersebut.

b. Mengemukakan manfaat pelajaran bagi kehidupan peserta didik baik untuk masa sekarang dan atau untuk berbagai aktivitas di masa mendatang.

c. Menggunakan bahasa yang jelas atau contoh-contoh yang ada hubungannya dengan pengalaman nyata atau nilai-nilai yang dimiliki peserta didik. Bahasa yang jelas yaitu bahasa yang dimengerti oleh peserta didik. Pengalaman nyata atau pengalaman yang langsung dialami peserta didik dan dapat menjembataninya ke hal-hal baru.

\section{Interest (Minat/ Perhatian)}

Interest ini berhubungan dengan minat. Menurut Woodruff (Rahman, 2014:188) bahwa sesungguhnya belajar tidak terjadi tanpa ada minat. Keller (Rahman, 2014) menyatakan bahwa dalam kegiatan pembelajaran minat tidak hanya harus dibangkitkan melainkan juga harus dipelihara selama kegiatan pembelajaran berlangsung. Oleh karena itu, guru harus memperhatikan berbagai bentuk cara mengajar dan memfokuskan minat dalam kegiatan pembelajaran. Adapun cara-cara yang dapat dilakukan untuk meningkatkan minat peserta didik dalam belajar adalah sebagai berikut:

a. Menggunakan cerita, analogi, sesuatu yang baru, dan menampilkan sesuatu yang aneh yang berbeda dari biasanya dalam pembelajaran.

b. Memberi kesempatan kepada peserta didik untuk berpartisipasi secara aktif dalam pembelajaran, misalnya para peserta didik diajak berdiskusi untuk memilih topik yang akan dibicarakan, mengajukan pertanyaan atau mengemukakan masalah yang perlu dipecahkan.

c. Mengadakan variasi dalam kegiatan pembelajaran, misalnya variasi dari serius ke humor, dari cepat ke lambat, dari suara keras ke suara yang sedang, dan mengubah gaya mengajar.

d. Mengadakan komunikasi nonverbal dalam kegiatan pembelajaran seperti demonstrasi dan simulasi.

\section{Assessment (Evaluasi)}


Komponen keempat model pembelajaran ARIAS adalah assessment, yaitu yang berhubungan dengan evaluasi terhadap peserta didik. Bagi guru, assessment merupakan alat untuk mengetahui apakah yang telah diajarkan sudah dipahami oleh peserta didik; untuk memonitor kemajuan peserta didik sebagai individu maupun sebagai kelompok; untuk merekam apa yang telah peserta didik capai, dan untuk membantu peserta didik dalam belajar. Bagi peserta didik, evaluasi merupakan umpan balik tentang kelebihan dan kelemahan yang dimiliki, dapat mendorong belajar lebih baik dan meningkatkan motivasi berprestasi. Evaluasi terhadap peserta didik dilakukan untuk mengetahui sampai sejauh mana kemajuan yang telah mereka capai dan apakah peserta didik telah memiliki kemampuan seperti yang dinyatakan dalam tujuan pembelajaran.

Beberapa cara yang dapat digunakan untuk melaksanakan evaluasi antara lain yaitu mengadakan evaluasi dan memberi umpan balik terhadap kinerja peserta didik, memberikan evaluasi yang obyektif dan adil serta segera menginformasikan hasil evaluasi kepada peserta didik, memberi kesempatan kepada peserta didik mengadakan evaluasi terhadap diri sendiri, memberi kesempatan kepada peserta didik untuk mengadakan evaluasi terhadap teman.

\section{Satisfaction (Penguatan)}

Satisfaction merupakan segala hal yang berhubungan dengan rasa bangga dan puas atas hasil yang dicapai. Dalam teori belajar satisfaction adalah reinforcement (penguatan). Peserta didik yang telah berhasil mengerjakan atau mencapai sesuatu merasa bangga atau puas atas keberhasilan tersebut. Keberhasilan dan kebanggaan itu menjadi penguat bagi peserta didik tersebut untuk mencapai keberhasilan berikutnya. Beberapa cara yang dapat dilakukan untuk meningkatkan rasa bangga pada peserta didik yaitu memberi penguatan (reinforcement), penghargaan yang pantas baik secara verbal maupun non-verbal kepada peserta didik yang telah menampilkan keberhasilannya, memberi kesempatan kepada peserta didik untuk menerapkan pengetahuan atau keterampilan yang baru diperoleh dalam situasi nyata atau simulasi, memperlihatkan perhatian yang besar kepada peserta didik, sehingga mereka merasa dikenal dan dihargai oleh para guru, dan memberi kesempatan kepada peserta didik untuk membantu teman mereka yang mengalami kesulitan atau memerlukan bantuan. 


\section{HASIL BELAJAR MATEMATIKA}

Hasil belajar adalah sesuatu yang diperoleh dari pembelajaran yang telah dievaluasi. Hasil belajar dapat berupa dampak pengajaran dan dampak pengiring. Kedua dampak tersebut bermanfaat bagi guru dan peserta didik.

Hasil belajar adalah bila seseorang telah belajar akan terjadi perubahan tingkah laku pada orang tersebut. Misalnya dari tidak tahu menjadi tahu, dan dari tidak mengerti menjadi mengerti . Hasil belajar merupakan hal yang dapat dipandang dari dua sisi yaitu sisi peserta didik dan dari sisi guru, dari sisi peserta didik, hasil belajar merupakan tingkat perkembangan mental yang lebih baik bila dibandingkan pada saat sebelum belajar. Tingkat perkembangan mental tersebut terwujud pada jenis-jenis ranah kognitif, afektif, dan psikomotor. Sedangkan dari sisi guru, hasil belajar merupakan saat terselesaikannya bahan pelajaran.

Berdasarkan pengertian di atas maka dapat disimpulkan bahwa hasil belajar matematika adalah suatu penilaian akhir dari proses dan pengenalan yang telah dilakukan berulang-ulang, dan kemampuan yang telah dimiliki setelah belajar pelajaran matematika serta menghasilkan perubahan yang berhubungan dengan pelajaran matematika ke arah yang lebih baik.

\section{METODE PENELITIAN}

Pendekatan yang digunakan adalah pendekatan penelitian kuantitatif. Penelitian ini menggunakan jenis eksperimen, Menurut Mania (2013:60) Penelitian Eksperimen yaitu bagian dari metode kuantitatif, dan memiliki ciri khas tersendiri terutama dengan adanya kelompok kontrol Dalam desain ini terdapat dua kelompok, kelompok eksperimen dan kelompok kontrol. Kelompok eksperimen adalah kelompok yang diajar dengan model pembelajaran ARIAS dan kelompok kontrol adalah kelompok yang diajar dengan model pembelajaran Konvensional.

Menuru Basuki (2006:182) Populasi dapat didefinisikan sebagai keseluruhan objek yang diteliti. Populasi pada penelitian ini adalah seluruh peserta didik Kelas VII SMPN 1 Sungguminasa Kabupaten Gowa Kabupaten Gowa tahun ajaran 2015-2016. Jumlah seluruh populasi 520 orang yang tersebar dalam 13 kelas (kelas VIIA - VIIM). Teknik pengambilan sampel dalam penelitian ini adalah secara acak (random) yaitu Simple random sampling. Untuk itu, peneliti memilih dua kelas secara acak untuk dijadikan sebagai sampel dengan cara undian untuk menentukan kelas eksperimen dan kelas kontrol. Setelah peneliti melakukan teknik tersebut maka peneliti 
mendapatkan sampel yang terdiri dari dua kelas yaitu peserta didik Kelas VIIB dengan jumlah peserta didiknya 40 orang dan VIIE dengan jumlah peserta didiknya juga 40 orang.

Menurut Mahmud (2011: 168) Observasi merupakan teknik pengamatan dan pencatatan sistematis dari fenomena-fenomena yang diselidiki. Sumber data dalam penelitian ini adalah peserta didik Kelas VIIb sebagai kelas eksperimen dan VIIe SMPN 1 Sungguminasa Kabupaten Gowa sebagai kelas kontrol. Teknik pengumpulan data yang digunakan berupa tes uraian hasil belajar dan lembar observasi. Pada tahap analisis data yang didasarkan data sampel, dianalisis dengan menggunakan teknik analisis statistik deskriptif dan analisis Statistik Inferensial. Analisis statistik deskriptif yang dimaksud seperti mean, median, modus, persentil, desil, kuartil, dalam bentuk analisis angka maupun gambar/diagram. Statistik inferensial yang dipakai adalah: Uji Normalitas, Uji Homogenitas dan Pengujian Hipotesis.

\section{HASIL PENELITIAN DAN PEMBAHASAN}

Analisis Deskripsi Hasil Belajar Matematika Peserta Didik yang Diajar dengan Menggunakan Model Pembelajaran ARIAS pada Kelas Eksperimen.

Berdasarkan hasil analisis dengan menggunakan output SPSS, maka dapat diketahui dari 40 peserta didik memiliki nilai terendah yang diperoleh pada kelas eksperimen adalah 50 dan nilai tertinggi adalah 100. Nilai rata-rata yang diperoleh adalah 76,90 dengan standar deviasinya adalah 14,05 dan variansi nilainya adalah 197.631 menunjukkan tingkat keragaman data.

Berdasarkan pengkategorian data maka dapat diketahui bahwa tingkat penguasaan materi peserta didik pada Posttest terdapat $0 \%$ peserta didik berada pada kategori sangat rendah, 3 peserta didik (7,5\%) berada pada kategori rendah, terdapat 8 peserta didik $(20 \%)$ berada pada kategori sedang, 15 peserta didik $(37,5 \%)$ berada pada kategori tinggi, dan 14 peserta didik (35\%) yang berada pada kategori sangat tinggi.

Analisis deskripsi Hasil Belajar Matematika Peserta didik yang di ajar dengan menggunakan Model Pembelajaran Konvensional pada Kelas Kontrol

Berdasarkan hasil analisis output SPSS, maka dapat diketahui dari 40 peseta didik memiliki nilai terendah yang diperoleh pada kelas kontrol adalah 40 dan nilai tertinggi adalah 96. Nilai rata-rata yang diperoleh adalah 65,32 
dengan standar deviasinya dan varians menujukkan tingkat keragaman data dengan nilai adalah 15,55 dan varians nya 241.917

Berdasarkan hasil pengkategorian data maka dapat diketahui bahwa tingkat penguasaan materi peserta didik pada Posttest terdapat $0 \%$ peserta didik berada pada kategori sangat rendah, 12 peserta didik $(30 \%)$ berada pada kategori rendah, terdapat 8 peserta didik (20\%) berada pada kategori sedang, 14 peserta didik (35\%) berada pada kategori tinggi, dan 6 peserta didik (15\%) yang berada pada kategori sangat tinggi.

Analisis Inferensial hasil belajar matematika yang di ajar menggunakan Model Pembelajaran ARIAS dengan Model Pembelajaran Konvensional pada peserta didik kelas VII SMPN 1 Sungguminasa Kabupaten Gowa

a. Uji Normalitas

Pengujian normalitas yang dilakukan terhadap posttest data hasil belajar matematika pada data kelas eksperimen, ditetapkan taraf signifikannya adalah 0,05 setelah dilakukan pengolahan data pada SPSS maka diperoleh output nilai sign untuk posttest kelas eksperimen sebesar 0,200 berarti nilai sig lebih besar dari nilai a $(0,200>0,05)$, H0 diterima atau tidak siginifikan. Dengan demikian, data populasi Kelas eksperimen berdistribusi normal.

Pengujian normalitas yang dilakukan terhadap posttest data hasil belajar matematika pada data kelas kontrol, ditetapkan taraf signifikannya adalah 0,05. setelah dilakukan pengolahan data pada SPSS maka diperoleh output nilai sign untuk posttest kelas eksperimen sebesar 0,200 berarti nilai sig lebih besar dari nilai a $(0,200>0,05)$, H0 diterima atau tidak siginifikan. Dengan demikian, data populasi Kelas kontrol berdistribusi normal

b. Uji Homogenitas

Berdasarkan output SPSS pada tabel Homogenity of Variences, diperoleh $\mathrm{F}=0.091 ; \mathrm{db} 1=1 ; \mathrm{db} 2=78$ dan nilai sign sebesar 0,764 , berarti nilai sig lebih besar dari nilai $\alpha=0,05(0,764>0,05)$. Dengan demikian H0 di terima. Maka dapat disimpulkan bahwa data posttest dari kelas eksperimen dan kelas kontrol bersifat homogen.

c. Pengujian Hipotesis

Teknik pengujian yang digunakan adalah uji $t$ sampel independen dengan taraf signifikan $\alpha=0,05$.Berdasarkan hasil perhitungan Statistical Package For Social Science (SPSS) pada kolom Equal variances assusmed dan baris Levene's test for Equality diperoleh $\mathrm{F}=0.091$ dengan angka diperoleh nilai 
signifikan $=0.764$ karena nilai sig $>$ a $(0,764>0,05)$, berarti varians populasi kedua kelompok homogen atau sama. Karena varians data homogen, maka akan dipilih kolom Equal variences assumed, dan pada baris t-test Equality means diperoleh harfa $\mathrm{t}=3.492, \mathrm{db}=78$ dan sig. $(2$ tailed $)=0.001 / 2=0.0005<$ 0.005, atau H0 ditolak. Dengan demikian, hipotesis yang diajukan teruji oleh data, sehingga disimpulkan bahawa terdapat perbedaan yang signifikan antara hasil belajar matematika peserta didik kelas VII SMPN 1 Sungguminasa Kabupaten Gowa yang diajar melalui Model Pembelajaran ARIAS dan model pembelajaran Konvensional.

Penelitian dilakukan selama satu bulan, dalam setiap pertemuan peneliti menerapkan 5 komponen dalam pembelajaran pada kelas eksperimen yaitu Assurance, Relevance, Interest, Assesment, Satisfaction sedangkan pada kelas control tidak diberikan perlakuan khusus. Hasil observasi dari penelitian yang didapatkan dari kelas eksperimen menunjukkan peneliti sudah baik dalam menerapkan komponen ARIAS, pada komponen assurance dapat membuat peserta didik menjadi percaya diri dalam pembelajaran matematika, karena dalam setiap pertemuan pembelajaran peneliti selalu menyakan kesiapan belajar peserta didik, dan memberika motivasi agar peserta didik yakin bahwa mereka dapat mengerti pembelajaran yang akan mereka pelajari.

Komponen relevance yang diterapkan oleh peneliti dapat membuat peserta didik mengetahui kaitan materi transformasi yang dipelajari dengan kehidupan sehari-hari peserta didik, peneliti menggunakan benda-benda atau contoh yang berada disekitar peserta didik, peneliti mengemukakan tujuan sasaran yang akan dicapai. Komponen interest juga membuat peserta didik memiliki ketertarikan terhadap materi yang disampaikan oleh peneliti, strategi yang digunakan oleh peneliti yaitu menggunakan permainan dalam sela-sela pemberian materi dan peneliti mengecek kondisi konsentrasi belajar peserta didik.

Komponen assesment dan satisfacttion dalam penelitian ini juga sering digunakan di setiap rancangan pembelajaran, dalam pembelajaran pasti memerlukan adanya evaluasi dan penguatan kepada peserta didik. Dalam penelitian berlangsung peneliti mengevaluasi pembelajaran dengan memberikan kesempatan peserta didik untuk dapat menilai dari hasil presentasi teman yang lain, dan peneliti juga memperhatikan proses yang berlangsung selama pembelajaran. Kemudian pada komponen penguatan peneliti menerapkan strategi dengan memberikan penghargaan kepada 
peserta didik yang aktif dan menyuruh peserta didik untuk menuliskan apa yang mereka dapatkan selama pembelajaran.

Pengolahan data yang diperoleh dari tes hasil belajar (tes uraian) dengan jumlah soal 6 nomor, didapatkan hasil belajar matematika peserta didik yang diajar dengan model pembelajaran ARIAS rata-rata nilai yang didapatkan peserta didik yaitu 76,90, hal ini menunjukkan bahwa rata-rata hasil belajar peserta didik berada pada kategori tinggi. Hasil belajar matematika peserta didik yang diajar dengan model pembelajaran Konvensional rata-rata nilai yang didapatkan peserta didik yaitu 65,32, hal ini menunjukkan bahwa rata-rata hasil belajar peserta didik berada pada kategori tinggi dan analisis inferensial diperolah $t$-hitung $>$ t-tabel dimana, $t$-hitung $=$ 3,492 sedangkan $t$-tabel $=2,000$, maka berdasarkan kriteria pengujian dapat dikatakan bahwaterdapat perbedaan rata-rata hasil belajar matematika peserta didik yang diajar dengan model pembelajaran ARIAS dengaan model pembelajaran konvensional pada kelas VII SMPN 1 Sungguminasa Kab. Gowa.

Hal ini sejalan dengan penelitian yang dilakukan oleh Hindayani (2013) yang menyimpulkan bahwa hasil belajar matematika peserta didik diperoleh nilai rata-rata kelas eksperimen dengan kelas berbeda. Dari perbedaan ratarata kedua kelas maka terdapat perbedaan signifikan hasil belajar matematika kelas eksperimen yang diajar dengan model pembelajaran ARIAS dengan kelas kontrol yang diajar model pembelajaran secara konvensional, serta penggunaan model pembelajaran ARIAS berpengaruh positif terhadap hasil belajar matematika pada peserta didik kelas IV di SD Negri 5 Batur Kecamatan Kintamani.

\section{SIMPULAN}

Hasil belajar matematika peserta didik yang diajar dengan model pembelajaran ARIAS rata-rata nilai yang didapatkan peserta didik yaitu 76,90, hal ini menunjukkan bahwa rata-rata hasil belajar peserta didik berada pada kategori tinggi. Hasil belajar matematika peserta didik yang diajar dengan model pembelajaran konvensional rata-rata nilai yang didapatkan peserta didik yaitu 65,32, hal ini menunjukkan bahwa rata-rata hasil belajar peserta didik berada pada kategori tinggi. Berdasarkan hasil analisis inferensial diperolah $t$-hitung $>$ t-tabel dimana, $t$-hitung $=3,492$ sedangkan $t$-tabel $=$ 2,000, maka berdasarkan criteria pengujian dapat dikatakan bahwa terdapat perbedaan rata-rata hasil belajar matematika peserta didik yang diajar dengan 
model pembelajaran ARIAS dengaan model pembelajaran konvensional pada kelas VII SMPN 1 Sungguminasa Kab. Gowa.

\section{DAFTAR PUSTAKA}

Badan Standar Nasional Pendidikan. (2006). Standar isi untuk satuan pendidikan dasar dan menengah (standar kompetensi dan kompetensi SMP/Mts). Jakarta: BSNP.

Basuki, S. (2006). Metode penelitian. Jakarta : Wedatama WIDYA Sastra.

Bohlin, R. (1987). Development and use of the arcs model of instructional design. Journal of Instructional Development.

Dimyati \& Madjiono. (1999). Belajar dan pembelajaran. Jakarta: Rineka Cipta.

Endang M. (2014). Metode peneltian terapan bidang pendidikan. Bandung: Alfabeta.

Hamalik O. (2006). Proses belajar mengajar I. Jakarta : PT. Bumi Aksara.

Herumen. (2007). Model pembelajaran matematika disekolah dasar. Bandung: PT Remaja Rosdakarya.

Mahmud. (2011). Metodologi penelitian pendidikan. Bandung: Pustaka Setia.

Mania, S. (2013). Metode penelitian pendidikan dan sosial. makassar: Alauddin University Press.

Margunayasa, I. G. (2013). Pengaruh model pembelajaran arias terhadap hasil belajar IPA kelas IV SD Negeri 3 Banjar Jawa. Journal UNDIKSHA.

Nursalam. (2013). Strategi pembelajaran matematika teori dan aplikasi bagi mahasiswa PGMI. Makassar: Alauddin University Press.

Rahman, M. (2014). Model pembelajaran ARIAS terintegratif. Jakarta: PT. Prestasi Pustaka.

Slameto. (2010). Belajar \& Faktor-faktor yang mempengaruhinya. Jakarta: PT. Rineka Cipta.

Sudjana, N \& Ibrahim. (2009). Penelitian dan penilaian pendidikan. Bandung: Sinar Baru Algesindo. 
Pengaruh Model Pembelajaran ARIAS....

Yasin, S. \& Borahima. (2010). Pengolaan pembelajaran. Makassar: Alauddin Press. 